\title{
DESIGN AND TRIAL OF CHEMISTRY POCKETBOOK CONTAINED SCIENCE GENERIC SKILLS
}

\author{
Susi Susanti ${ }^{1 *}$, Pangoloan Soleman Ritonga ${ }^{2}$ \\ ${ }^{1,2}$ Chemistry Education Department, Universitas Islam Negeri Sultan Syarif Kasim, \\ Riau, Indonesia \\ *Email: antisusisusanti308@gmail.com
}

Website: http://jurnal.uin-antasari.ac.id/index.php/jtijk

Received: 10 February 2021; Accepted: 2 June 2021; Published: 24 June 2021

\begin{abstract}
This research aimed at developing a pocket book containing science generiC skills on Reaction Rate lesson and knowing validity level, practicality level, and student response to the developed pocket book. It was Research and Development (R\&D) with Borg and Gall model. The subjects of this research were 10 the twelfth-grade students of Natural Science 3 at Islamic Senior High School of Darul Hikmah Pekanbaru. The object was the pocket book containing science generik skills on Reaction Rate lesson. Validity test questionnaire, practicality test questionnaire, student response test questionnaire, interview, and documentation were the techniques of collecting the data. Analyzing the data was done by using qualitative and quantitative descriptive analysis techniques. The research findings showed that the validity level of the chemistry pocket book was $76.3 \%$ (valid), the practicality level was $81.2 \%$ (very practical), and the percentage of student response to the pocket book was $84.2 \%$ (very good). It could be concluded that the chemistry pocket book containing science generik skills on Reaction Rate lesson could be tested wider.
\end{abstract}

Keywords: pocket book; science generik skills; reaction rate.

\section{INTRODUCTION}

Learning resources have an essential role in the learning process because the availability of adequate learning resources will assist teachers in facilitating the learning process so that the learning objectives can be achieved (Winarti, Wijianto, \& Winarto, 2018). The most commonly used learning resources are textbooks. According to Rahmawati, selecting the right learning resources will impact the success of the teacher's teaching. Therefore, teachers as educators should be careful and thorough in choosing learning resources. Furthermore, if students' learning resources are attractive to students, students will be motivated to learn independently (Rahmawati, Sudarmin, \& Pukan, 2013).

Today's problem is that most teachers do not develop their teaching materials but buy them from book agents.
Moreover, the teaching materials from these agents are not adapted to school conditions and student conditions (Kristianingsih, 2016). The textbooks circulating in the market have a relatively large size, namely $25 \mathrm{~cm}$ x $17.5 \mathrm{~cm}$, making it difficult to carry around. In addition, the reading descriptions on each page are relatively long. Furthermore, most of these books use few pictures and colors to have a less attractive appearance. These things cause students' low interest in reading (Ami, Susantini, \& Raharjo, 2012).

Based on the observations, MA Darul Hikmah Pekanbaru textbooks for their learning resources. However, students are less interested in reading the book, this is because the book is too thick and contains material that is too broad so that in every chemistry lesson, most students do not bring textbooks or left in the dormitory 
for severe reasons. Therefore we need a learning resource that makes students interested in seeing the book and reading the book. One of the learning resources that present material briefly or wordily is a pocketbook.

Pocketbooks are one of the tools that can be used in the learning process that conveys information about the subject matter and others that are one-way in nature to develop students' potential to become independent learners (Mustari \& Sari, 2017). In addition, learning resources are in the form of pocketbooks with small pocketsized sizes so that they are practical to carry everywhere and can read anytime when needed (Zuhra, Hasan, \& Safitri, 2017).

Pocketbooks can also make students easier to study under any circumstances. In addition to the book's small size, the contents in the book are more concise so that students can obtain information without wasting time trying to find out the essence of the information. In general, pocketbooks arranged in a format that contains a description of each chapter accompanied by an illustration of the material, where the end of each chapter ends with sample questions as well as discussion and evaluation of questions (Wulandari, Prihandono, \& Handayani, 2016).

The pocketbook developed through this research measures $10.5 \times 14.8 \mathrm{~cm}$ so that it is easy to carry anywhere, and the reading descriptions on each page are relatively short, concise, and straightforward. The presentation of this pocketbook uses pictures and colors that provide an attractive appearance so that it is expected to increase students' reading interest.

Generic science skills are skills for improving the quality of human resources in the 21 st century. Generic skills carried out in the field of science are called generic science skills. These skills are very useful for students to solve physics problems in the surrounding environment and during the learning process. Generic skills can be developed in science education and learning curricula (Sudianah, Makhrus, \& Taufik, 2021).

Generic science skills are the skills to think and act based on their scientific knowledge (Mujiyanti, Hakim, \& Hadisaputra, 2020). Generic science skills are essential (generic) skills needed to train students' scientific work to produce students who can understand concepts, solve problems and other scientific activities, and learn on their own effectively and efficiently. Generic science skills can be grown when students go through chemistry, one of which is to learn various concepts and solve various science problems (Rosidah, Astuti, \& Wulandari, 2017).

In learning chemistry, especially on the reaction rate material, it is necessary to develop generic science skills in learning. Where the reaction rate material contains material concepts and the formulas contained in it, then in studying the reaction rate material, a good understanding is needed. The purpose of designing teaching materials does not just emphasize the mission of delivering knowledge/facts. However, it is designed to develop generic science skills to produce students who can understand concepts, solve problems and other scientific activities, and learn independently and efficiently.

Teaching materials in the form of a pocketbook on the subject of acid and base developed by Wati, Erviyenni, \& Holiwarni were declared valid to meet the appropriateness of content, language, presentation, and graphics. The overall average score of pocketbook validation is $91.92 \%$, with a very valid category. The teacher and student response trials results were $90 \%$ and $93.57 \%$, respectively, with very good criteria so that pocketbooks were declared practical for students to use in learning (Wati, Erviyenni, \& Holiwarni, 2019).

Based on the description above, the researchers are interested in designing alternative teaching materials in a pocketbook containing generic science 
skills. The research aimed to determine the level of validity, practicality, and student responses to the chemistry pocketbook produced.

\section{RESEARCH METHOD}

This research belongs to the type of research and development (R \& D). The design of this chemistry pocketbook uses the Borg \& Gall model, which consists of 10 stages of research and development, namely: 1) research and information gathering, 2) planning, 3) initial product development, 4) initial product field testing, 5) initial product revision. , 6) field test of the product on a broader scale, 7) revision of the product, 8) field test in a broader scale, 9) revision of the final product based on the results of data analysis in the final field test, and 10) dissemination and reporting of the final product. Research and development (Sanjaya, 2013). However, this research is limited to stage 5, namely: product revision based on the initial product field test results.

The research was conducted in the even semester of the 2019/2020 academic year at MA Darul Hikmah Pekanbaru. The study conducted in March 2020. The subjects in this study were ten students of class XII IPA 3 MA Darul Hikmah Pekanbaru, who acted as respondents. At the same time, the object of this research is a pocketbook containing generic science skills on the reaction rate material. The pocketbook validators consisted of 1 expert lecturer on learning materials, one expert lecturer on learning media, and two chemistry teachers.

Data collection techniques consist of: (1) interviews. This technique is used in the introduction to find problems, obstacles, and difficulties faced in learning chemistry at school. The information obtained is used for needs analysis which is the initial stage of development research. The researcher conducted an unstructured interview with the chemistry teacher and students of MA Darul Hikmah Pekanbaru. (2) Questionnaire, the questionnaire used is based on the calculation scale of the National Education Standards Agency (BSNP), including a validity test questionnaire by material experts and learning media experts, practicality test questionnaires by teachers, and student response questionnaires.

Documentation, documentation in this study is in the form of school profile data in school conditions, number of students, and data that supports other research.

Table 1. Research Questionnaire Scale.

\begin{tabular}{ll}
\hline Item Instruments & Score \\
\hline Very Good & $9-10$ \\
Good & $6-8$ \\
Bad & $4-5$ \\
Very bad & $1-3$ \\
\hline (BSNP 2014)
\end{tabular}

(BSNP, 2014)

The data analysis technique used is descriptive qualitative data analysis technique and quantitative descriptive analysis technique. Qualitative descriptive analysis is done by analyzing qualitative data in the form of words, not in the form of numbers (Trianto, 2010)

The qualitative descriptive analysis technique was used to process the data from the assessment results in the form of comments and suggestions by validators and respondents, which were then analyzed descriptively. At the same time, quantitative descriptive analysis is done by analyzing quantitative data in the form of numbers (Trianto, 2010). Quantitative descriptive analysis technique was used to analyze the data from the questionnaire assessment by validators and respondents. The quantitative descriptive analysis techniques are as follows:

1) Determine the maximum score

Score $\max =$ number of items $\times$ score $\max$

2) Determine the score obtained by adding up the scores from each validator. To determine percentage:

$$
\%=\frac{\text { score acquired }}{\text { ideal max score }} \times 100 \%
$$


3) The percentage results are then interpreted according to the assessment criteria table (Riduwan, 2012).

Each table of assessment criteria is described below.

Table 2. Validity Test Assessment Criteria.

\begin{tabular}{lll}
\hline No. & Interval & Criteria \\
\hline 1 & $81 \%-100 \%$ & Very Valid \\
2 & $61 \%-80 \%$ & Valid \\
3 & $41 \%-60 \%$ & Valid Enough \\
4 & $21 \%-40 \%$ & Less Valid \\
5 & $0 \%-20 \%$ & Unvalid \\
\hline \multicolumn{2}{l}{ Riduwan, 2012) }
\end{tabular}

Table 3. Practicality Test Assessment Criteria.

\begin{tabular}{lll}
\hline No. & Interval & Criteria \\
\hline 1 & $81 \%-100 \%$ & Very Practical \\
2 & $61 \%-80 \%$ & Practical \\
3 & $41 \%-60 \%$ & Practical Enough \\
4 & $21 \%-40 \%$ & Less Practical \\
5 & $0 \%-20 \%$ & Unpractical \\
\hline
\end{tabular}

Table 4. Student Response Test Assessment Criteria.

\begin{tabular}{lll}
\hline No. & Interval & Criteria \\
\hline 1 & $81 \%-100 \%$ & Very Good \\
2 & $61 \%-80 \%$ & Good \\
3 & $41 \%-60 \%$ & Good Enough \\
4 & $21 \%-40 \%$ & Bad \\
5 & $0 \%-20 \%$ & Very Bad \\
\hline
\end{tabular}

\section{RESULTS AND DISSCUSSION}

This research produces a product in the form of a pocketbook containing generic science skills on the reaction rate material. The pocketbook is designed using the Borg and Gall model. The stages of the Borg \& Gall development model are quite ideal. Borg suggests that at least three trials produce reliable educational products, starting from minimal trials to more extensive trials. However, referring to Borg's explanation, the ideal stage can be simplified without reducing the value of research and development itself (Sanjaya, 2013). Therefore, due to the limitations of the research carried out, the research was simplified to only five stages of research and development, namely: 1) research and information gathering, 2) planning, 3) initial product development, 4) initial product field testing, 5) revision initial product. The result data from each stage carried out are described as follows.

\section{a. Research and Gathering information}

The research and information gathering phase consisted of a literature study and a field survey. Literature studies are carried out by reading and discussing journals to collect various information related to the research to be carried out, namely chemistry pocketbooks.

Furthermore, a field survey was carried out, which was useful to complement the research literature in providing the basic knowledge for designing a chemistry pocketbook product. The field survey was conducted by interviewing chemistry teachers and students of class XI IPA 3 MA Darul Hikmah Pekanbaru.

Based on the interview results, the chemistry learning resources used by students are textbooks. In every chemistry lesson, most students do not bring their textbooks to class for various reasons, some of which say textbooks are heavy, forgetfulness, and reasons for borrowing a friend's book. In addition, it is also known that most students rarely read textbooks when studying chemistry at home or in a dormitory for various reasons, including textbooks that are difficult to understand, reasons that are not interesting, and reasons for being lazy to read. Students prefer to read notebooks that contain a summary of the material that the teacher has delivered.

Therefore, alternative learning resources are needed that are small in size so that they are practically carried everywhere, have short reading descriptions on each page, have an attractive appearance, have complete material content and representative examples, and can train students' generic science skills. The learning resource that will be designed is a chemistry pocketbook containing generic science skills on the reaction rate material. 
A pocketbook is a small book that can be put in a pocket and easy to carry everywhere (Salim \& Salim, 1991). A pocketbook is a supplementary book or supplementary textbook that is helpful or in the form of an addition to the main textbook (lesson textbook) used by students. When students do not bring their textbooks during chemistry learning, pocketbooks are a solution for effective learning.

Complementary books such as pocketbooks are also needed to provide more learning resources which are expected to improve students' cognitive abilities (Satrianingsih, Haryani, \& Dewi, 2017). Therefore, a chemistry pocketbook will be designed that will present the material concisely and clearly, accompanied by pictures, evaluation questions, and answer keys that can function in training students' abilities. In addition, pocketbooks can also be used as media that convey information about the subject matter and others that are one-way in nature to develop the potential of students to become independent learners (Mustari \& Sari, 2017).

Pocketbooks are one of the tools that can be used in the learning process because pocketbooks have several functions: 1) an attention function, pocketbook media are printed in small and full-color packages to attract students' attention to concentrate on the content of the material presented. Written in it, 2) effective function, writing formulas on pocketbook media and there are pictures on the material description so that it can increase students' enjoyment in learning. 3) cognitive function, writing formulas and pictures can clarify the material contained in the pocketbook so that it can facilitate the achievement of learning objectives. 4) compensatory function, writing material in short and clear pocketbooks can help students who are weak in reading to understand the material in the text and recall it. 5) psychomotor function, writing short and clear pocketbook materials can make it easier for students to memorize it,
6) evaluation function, assessment of students' abilities in $\mathrm{m}$ understanding the material can be done by working on evaluation questions contained in pocketbooks (Sulistyani, Jamzuri, \& Raharjo, 2013).

In addition, the use of pocketbooks in learning also has several benefits, including 1) the delivery of material using pocketbooks can be uninformed. 2) the learning process using pocketbooks becomes clearer, fun, and engaging because of its attractive design and printed in full color. 3) efficient in time and energy, pocketbooks printed in small sizes can make it easier for students to carry and use whenever and wherever. 4) writing short and clear material and formulas in pocketbooks can improve the quality of student learning outcomes. 5) design Attractive and full-color pocketbooks can foster students' positive attitude towards the material and learning process (Sulistyani, Jamzuri, \& Raharjo, 2013).

The chemistry pocketbook designed by the researcher is a pocketbook containing generic science skills on the subject of reaction rates. Generic science skills are basic (generic) abilities needed to train students' scientific work so that they can produce students who are able to understand concepts, solve problems and other scientific activities, and able to learn on their own effectively and efficiently (Rosidah, Astuti, \& Wulandari, 2017).

The indicators for generic science skills include: 1) direct observation, 2) indirect observation, 3) awareness of scale, 4) symbolic language, 5) logical framework, 6) logical consistency, 7) law of cause and effect. ,8) mathematical modelling, 9) constructing concepts, and 10) abstraction (Tawil \& Liliasari, 2014). So with this pocketbook containing generic science skills, it is hoped that it can help students learn chemistry, especially on the reaction rate material. 


\section{b. Planning}

At this stage, the researcher makes a product design that will be designed in the form of a pocketbook containing generic science skills on the reaction rate material. This planning stage includes:

1) Curriculum Analysis

The curriculum analysis aims to ensure that the designed chemistry pocketbook is accurate and does not deviate from the Minister of Education and Culture syllabus. Therefore, curriculum analysis includes an analysis of Core Competencies (KI) and Basic Competencies (KD) and then translated into indicators of competency achievement.

The KD of the reaction rate material in the LKPD, including KD 3.6 Explaining the factors that affect the reaction rate using collision theory. KD 3.7 Determine the reaction order and reaction rate constant based on experimental data.

2) Preparation of structural framework

The purpose of preparing the framework is to determine the systematic format for writing a chemistry pocketbook draft. The systematic format for writing a chemistry pocketbook draft in this study is as follows:

a) Front page (cover)

b) Main title

c) Preface

d) Advantages of pocket books

e) Core competencies

f) Basic competence

g) Learning indicator

h) Table of contents

i) List of pictures

j) Concept map

k) Material reaction rate, including the following:

(1) Definition of reaction rate,

(2) Colission theory,

(3) Factors affecting the reaction rate

(4) Equation of reaction rate and reaction order

1) Evaluation questions

m) Answer keys

n) Glossary

o) Bibliography
The presentation of the material is designed to contain components of generic science skills. The components of generic science skills contained in the chemistry pocket book are as follows:

(1) Direct and indirect observation, collecting facts from experimental results or natural phenomena.

Pernahkah kamu menghidupkan api
menggunakan korek api kayu? Jika pernah,
ketika kamu menggesekkan batang korek api
nya, maka api akan menyala dengan sangat
cepat. Mengapa
demikian?Atau lain
halnya jika kamu
pernah memotong
buah apel, kemudian

Picture 1. Direct Observation.

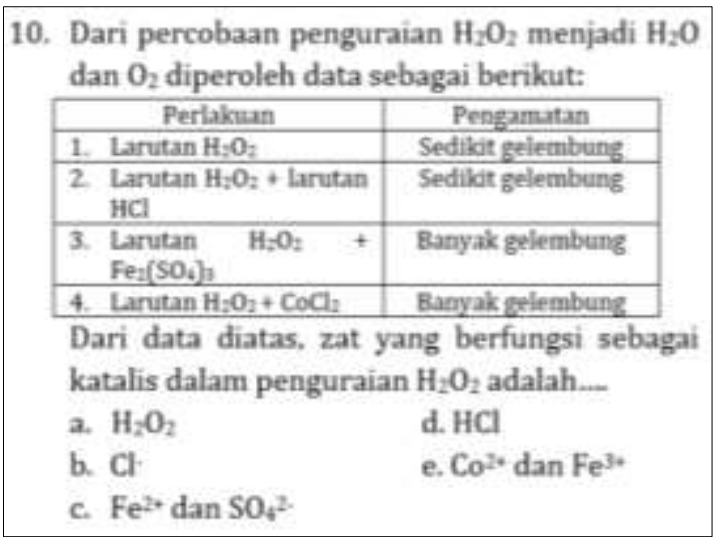

Picture 2. Indirect Observation.

(2) Awareness of scale, aware of natural objects and high sensitivity to numerical scales as a microscopic or macroscopic scale.. 


\section{Contoh Soa}

1. Pada reaksi $2 \mathrm{NH}_{3}(\mathrm{~g}) \rightarrow \mathrm{N}_{2}(\mathrm{~g})+3 \mathrm{H}_{2}(\mathrm{~g})$, konsentrasi $\mathrm{H}_{2}$ bertambah dari 0 menjadi $0,2 \mathrm{~mol} / \mathrm{L}$ dalam waktu 10 detik. Berapa laju reaksi $\mathrm{H}_{2}$ ?

Penyelesaian :

$\mathrm{VH}_{2}=+\frac{\Delta\left[\mathrm{H}_{2}\right]}{\Delta t}=\frac{0,2 \mathrm{~mol} \mathrm{~L}^{-1}}{10 \text { detik }}=\frac{0.02 \mathrm{~mol}}{L}$ detik

\section{Picture 3. Scale of Awareness}

(3) Symbolic language, as for some indicators of symbolic language including:

(a) Understand symbols, symbols, and terms.

(b) Understand the quantitative meaning of units and quantities from the equation.

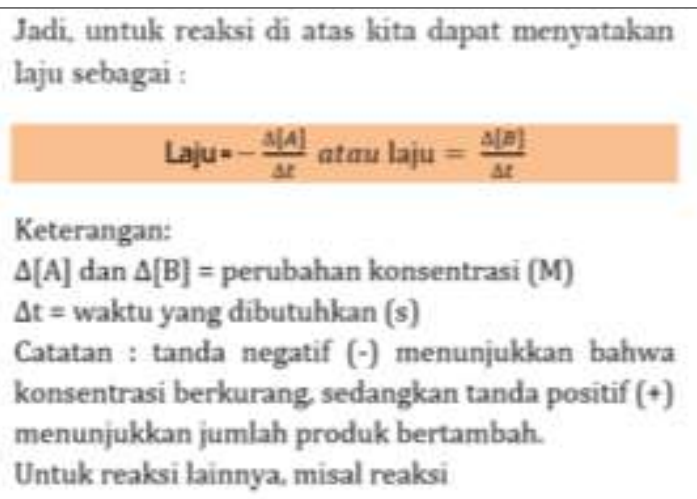

Picture 4. Symbolic Language (a dan b).

(c) Using mathematical rules to solve problems or natural phenomena.

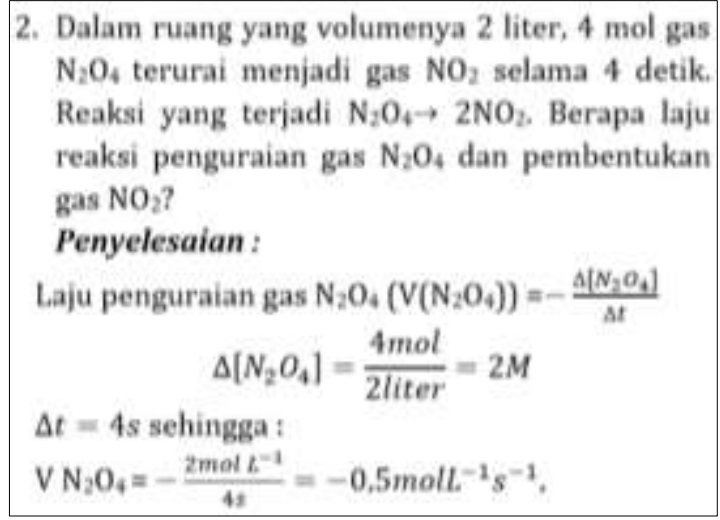

Picture 5. Symbolic Language (c).

(d) Reading a graph/diagram, table and mathematical sign.

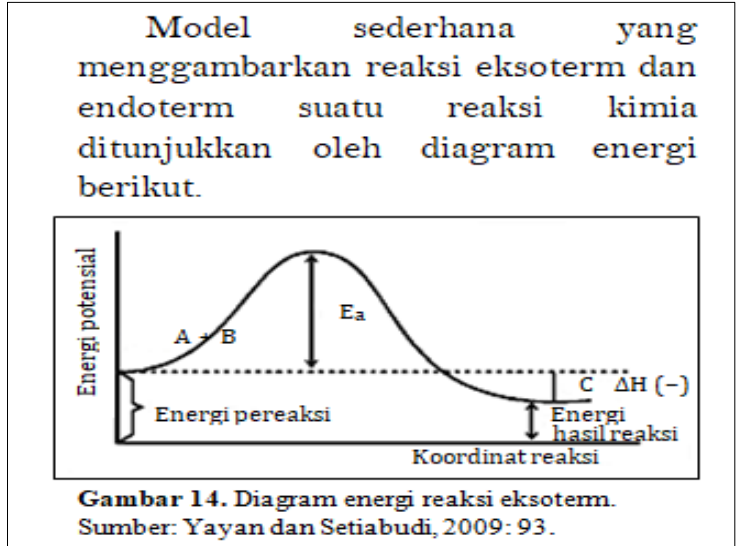

Picture 6. Symbolic Language (d).

(4) The framework of logic obedience principle (frame logic), looking for a logical relationship between two rules.

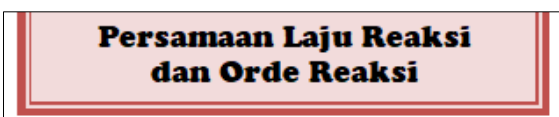

Hubungan antara konsentrasi reaktan dengan laju reaksi secara keseluruhan dalam suatu reaksi kimia, dapat dituliskan dalam bentuk persamaan laju reaksi. Persamaan laju reaksi hanya dapat dinyatakan berdasarkan percobaan. Misalkan untuk reaksi berikut (Tim Mas Media, 2016 : 107-108).

$$
p \mathrm{~A}+q \mathrm{~B} \rightarrow r \mathrm{C}+s \mathrm{D}
$$

Persamaan laju reaksinya :

$$
v=k[\mathrm{~A}]^{\mathrm{x}}[\mathrm{B}]^{\mathrm{y}}
$$

\section{Picture 7. The Principles of Obedience Logic} Framework

(5) Logical consistency, understanding the rules, arguing based on rules, explaining problems, and drawing conclusions from a phenomenon based on previous rules/laws.

1. Dari hasil percobaan, untuk reaksi :

A $+B \rightarrow$ produk reaksi, didapatkan data sebagai berikut :

\begin{tabular}{|c|c|c|c|c|}
\hline \multirow{2}{*}{ Percobaan } & \multicolumn{2}{|c|}{ Pereaksi } & Waktu & Suhu \\
\cline { 2 - 3 } & A & B & $($ s) & $\left({ }^{\circ} \mathrm{C}\right)$ \\
\hline 1 & 5 gram serbuk & $0,1 \mathrm{M}$ & 2 & 25 \\
\hline 2 & 5 gram larutan & $0,1 \mathrm{M}$ & 3 & 25 \\
\hline 3 & 5 gram padatan & $0,1 \mathrm{M}$ & 5 & 25 \\
\hline 4 & 5 gram larutan & $0,2 \mathrm{M}$ & 1,5 & 25 \\
\hline 5 & 5 gram larutan & $0,1 \mathrm{M}$ & 2,5 & 25 \\
\hline
\end{tabular}

Berdasarkan data percobaan 1 dan 3 diatas, jelaskanlah faktor yang mempengaruhi kecepatan reaksi adalah?

Penyelesaian :

Pada percobaan 1 zat A berupa serbuk, sedangkan percobaan 3 zat A berupa padatan. Dapat disimpulkan bahwa kecepatan reaksi dipengaruhi oleh faktor luas permukaan. 
(6) The law of cause and effect, states the relationship between two or more variables in a certain natural phenomenon, and predicts the cause of that phenomenon.

2. Luas Permukaan
$\begin{aligned} & \text { Pernahkah kamu memasak } \\ & \text { menggunakan tunglku kayu } \\ & \text { bakar? Pada zaman modern } \\ & \text { ini sebagian besar orang } \\ & \text { sudah beralih dengan } \\ & \text { menggunalkan kompor gas } \\ & \text { untul memasak. }\end{aligned}$

$\mathrm{Hal}$ ini dikarenakan penggunaan kompor gas lebih efektif dan efisien. Namun tahukah kamu, ketika ingin memasak menggunakan kayu bakar, kayu tersebut harus dibelah dulu menjadi potongan yang lebih kecil.

Picture 9. The law of cause and effect.

(7) Mathematical modeling, expressing phenomena or problems in the form of drawing/graphic sketches.

1. Perhatikan percobaan berikut!

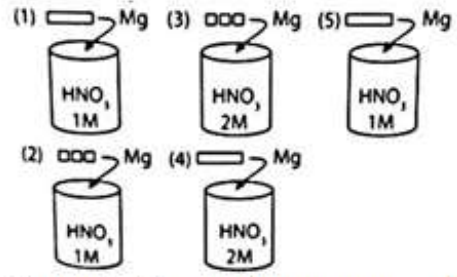

Sebanyak 5 gram logam magnesium masingmasing dilarutkan dalam 5 wadah yang berbeda. Laju reaksi yang hanya dipengaruhi oleh konsentrasi terdapat pada nomor?

Picture 10 Mathematical model.

(8) Building a concept, building a new concept.

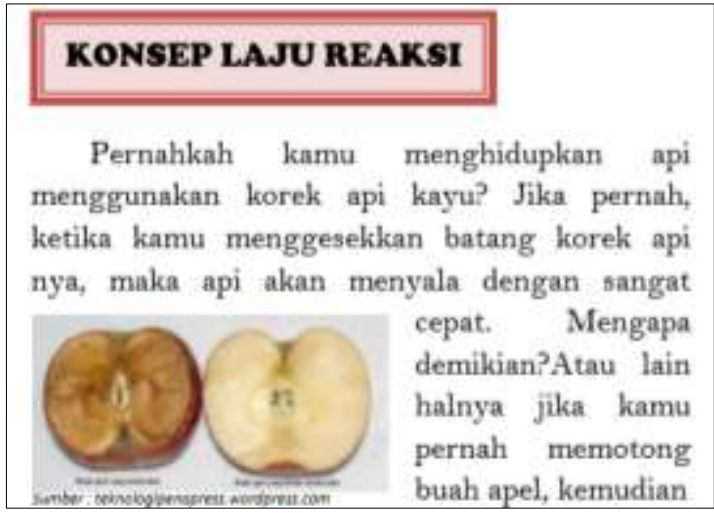

Picture 11. Concept building.
(9) Abstraction, students are led to explain a theory on the reaction rate material with the help of abstract images..

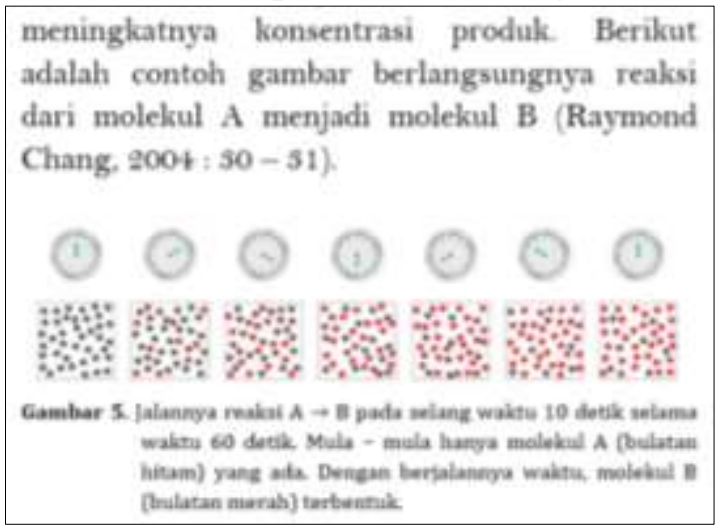

Picture 12. Abstraction.

3) Collecting references as material for writing chemistry pocketbooks.

References that can be used include university chemistry books, chemistry textbooks, journals, and various resources.

4) Writing chemistry pocket book.

Writing a chemistry pocketbook is necessary to focus on preparing the material text in a short, clear, and strived way to understand it easily. This chemistry pocketbook was created using Microsoft Word 2010 software and printed on a reciprocal A6 (10.5 $\times$ $14.8) \mathrm{cm}$ size.

5) Evaluating the results of writing After writing a chemistry pocket book, then to minimize typos/errors, it is necessary to evaluate the writing results. Evaluating the results of writing is done by re-reading.

6) Fixing the chemistry pocket book. If errors/typing errors are found, then make corrections to the deficiencies of the chemistry pocketbook. Then the final stage of the preparation of this chemistry pocketbook containing generic science skills is the printing process.

In addition to formulating a pocketbook product design, the researchers also prepared the instruments needed during the study, in the form of a questionnaire to test the validity of learning material experts, 
a questionnaire to test the validity of learning media experts, a practicality test questionnaire by the teacher, and a student response questionnaire.

\section{c. Early product development}

This stage is the stage of building the initial product of a chemistry pocketbook that can be tested in the field. However, before carrying out the initial product validation activities for the chemistry pocketbook, the instrument validation must first be carried out. The instruments that have been formulated are validated by lecturers who are experts in the field of instruments. The instrument validation process was carried out in 2 stages: initial instrument validation and instrument validation after revision. Thus, in the end, a valid instrument was obtained and was suitable for use in research.

After that, validation activities are carried out. Validation activities are estimates or judgments based on assessments from experts. Validation by experts is also needed to see the feasibility of the product at a more macro level (Sukmadinata, 2006). The description of the initial product validation of the chemistry pocketbook, including:

\section{1) Material Expert Validation}

Material expert validation aims to assess the feasibility of the content, presentation, and language of a chemistry pocketbook by a material expert lecturer. The validation process is carried out by giving the initial product a chemistry pocketbook and a validation sheet in the form of a validity test questionnaire to the validator. The validation of the chemistry pocketbook by material experts was carried out in 2 stages: initial validation and validation after revision.

In the initial validation results of the chemistry pocketbook, the validator has not filled out the questionnaire because there are still errors in the pocketbook that need improvement. The suggestions for improvement by the validator are as follows.
Table 5. Suggestion for improvement by Material Expert

Suggestions

a) Mynotes in the background should be removed.

b) The page number is not clear.

c) Pay attention to writing: font size, spacing, lowercase, uppercase letters, word choice, and placement of image captions.

d) Fix some errors in the reaction rate material.

The chemistry pocketbook was then revised according to suggestions for improvement. Based on the validation results after revision, the total average percentage by material experts was $73.1 \%$ with valid criteria.

\section{2) Media Expert Validation}

Media expert validation aims to assess the feasibility of a chemistry pocketbook graphic by a media expert lecturer. The validation process is carried out by giving the initial product a chemistry pocketbook and a validation sheet in the form of a validity test questionnaire to the validator. The validation of the chemistry pocketbook by material experts was carried out in 2 stages: initial validation and validation after revision.

In the initial validation results of the chemistry pocketbook, the validator has not filled out the questionnaire because there are still errors in the pocketbook that need improvement. The suggestions for improvement by the validator are as follows.

Table 6. Suggestions for Improvements by Media Experts.

\section{Suggestions}

a) Pay attention to the cover design

b) Pay attention to the background

c) Pay attention to the clarity and suitability of the image with the material and the placement of image descriptions

d) pay attention to some wrong material concepts.

The chemistry pocket book was then revised and based on the results of the 
validation after revision, the average percentage of the total by media experts was $79.5 \%$ with valid criteria.

\section{3) Results by Material Expert and Media Expert}

The average percentage of chemistry pocketbook validation results by material experts and media experts is $76.3 \%$ with valid criteria. It shows that the aspects of content feasibility, presentation feasibility, language feasibility, and graphic feasibility of a chemistry pocketbook containing generic science skills on the reaction rate material are valid and worthy of field testing.

The results of the validity test on each aspect are presented in the following figure.

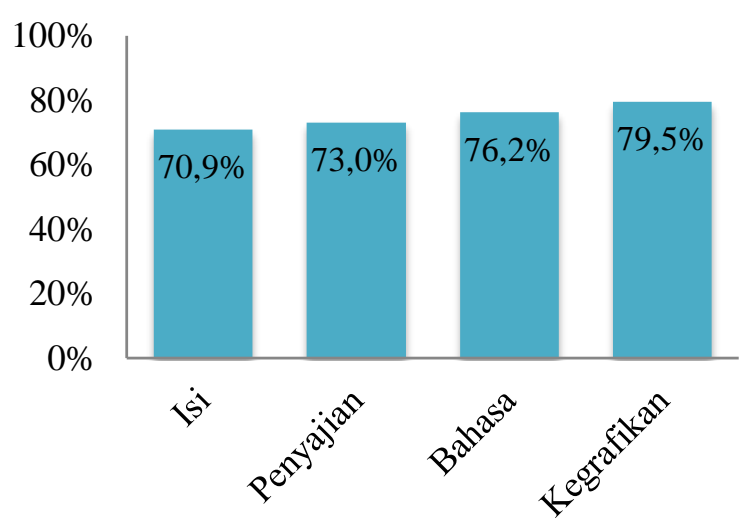

Picture 13. Diagram Result of Validity Test.

\section{d) Initial and Revised Product Field Test.}

Product validation by experts that have been carried out previously aims to obtain product feasibility on a more macro level. In contrast, the field test aims to obtain product feasibility on a more micro level because it is practised in real situations, both in terms of the situation and number of students and learning facilities and facilities following actual reality at school (Sukmadinata, 2006).

The initial product field test is the stage to see the feasibility of the chemical pocketbook product from the user's perspective, both teachers and students of MA Darul Hikmah Pekanbaru. At this initial product field test stage, the activities carried out were experimental trials by teachers and student responses to chemistry pocketbooks, described as follows.

\section{1) Teacher Practicalty Test}

The practicality test by the teacher was carried out to obtain the final design of the product before the student response test was conducted. The practicality test was aimed at aspects of content feasibility, presentation component, linguistic component, linguistic component, science generic skills component, and graphic feasibility of a chemistry pocketbook. Chemistry teachers carry out practicality tests because they have experience and insight into teaching practice in schools.

The practicality test validator of the chemistry pocketbook consists of 2 chemistry teachers. The practicality test was carried out by giving the chemistry pocketbook and practicality test questionnaire to the teacher.

The practicality test of the teacher's chemistry pocketbook obtained a total average percentage of $81.6 \%$ with convenient criteria. However, with a note that some improvements need to be made as follows.

Table 7. Teacher I suggestion

\begin{tabular}{l} 
Suggestion \\
\hline Pay attention to the spacing of each sentence and \\
the image of my notes is too contrasting to make \\
the existing writing less clear.
\end{tabular}

The chemistry pocketbook was then revised under the suggestions for improvement by teacher I. Meanwhile, the practicality test by teacher II obtained a total average percentage of $80.8 \%$ with practical criteria. The conclusions from teacher II are as follows.

Table 8. Teacher II conclusion . Teacher II conclusion

The chemistry pocket book deserves to be tested in the field without any revisions

Based on the results of the practicality test by the two teachers, it is 
known that the average practicality test results on the content feasibility aspect are $83.3 \%$, the presentation component is $82.5 \%$, the linguistic component is $80.0 \%$, the science generic skills component is $77.5 \%$, and the graphic feasibility $81.6 \%$. The total average percentage is $81.2 \%$ with very practical criteria and based on the assessments of the three teachers. It is known that the aspects of content feasibility, language feasibility, presentation feasibility, graphic feasibility, and the benefits of a chemistry pocketbook containing generic science skills on reaction rate material are very practical and deserve a limited trial.

Here are some views of changes in pocketbook products before and after going through improvements from the validity and practicality tests results.
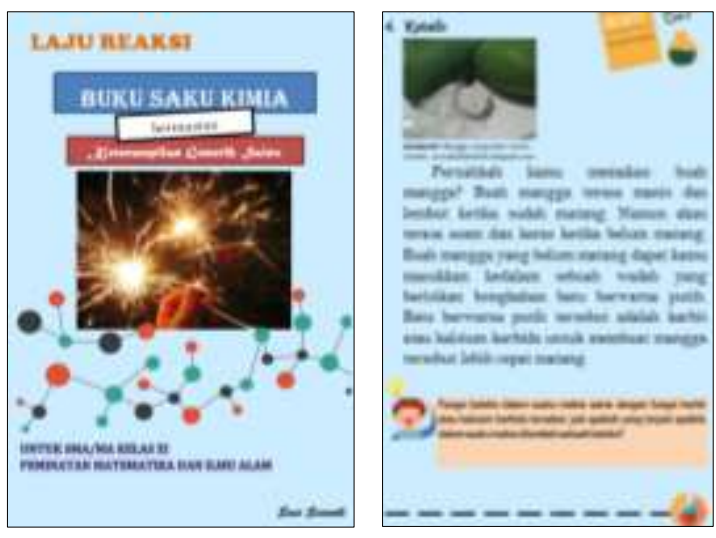

Picture 14. Product Appreance Before Revision.

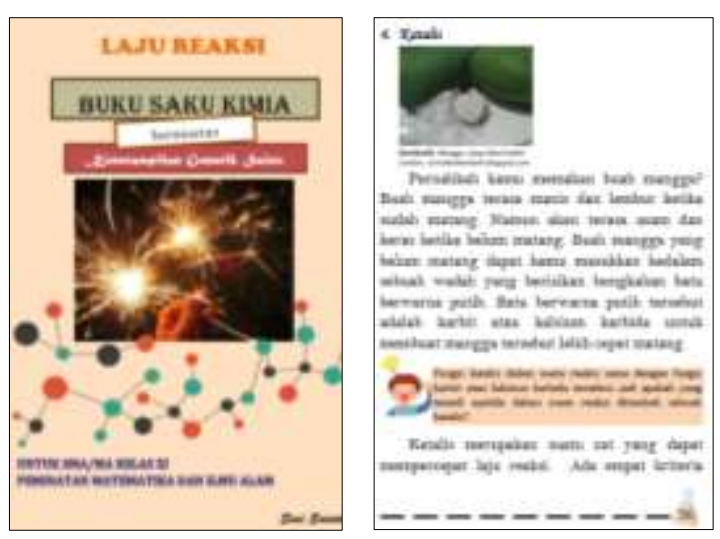

Picture 15. Product Appreance After Revision.

\section{2) Limited trial test}

The limited trial of chemistry pocketbooks involved 10 respondents, 54 namely students of class XII IPA 3 MA Darul Hikmah Pekanbaru. Student response data to the chemistry pocketbook was obtained by giving a response questionnaire after using the chemistry pocketbook.

Based on the student response test results, the total average percentage was $84.2 \%$, which means that the student's response to the chemistry pocketbook was very good. It shows that the student's response is very good to the pocketbook containing generic science skills on the reaction rate material is reviewed based on content quality, generic science skills, appearance, and language of the pocketbook.

The results of the student response questionnaires in each aspect are presented in the following picture:

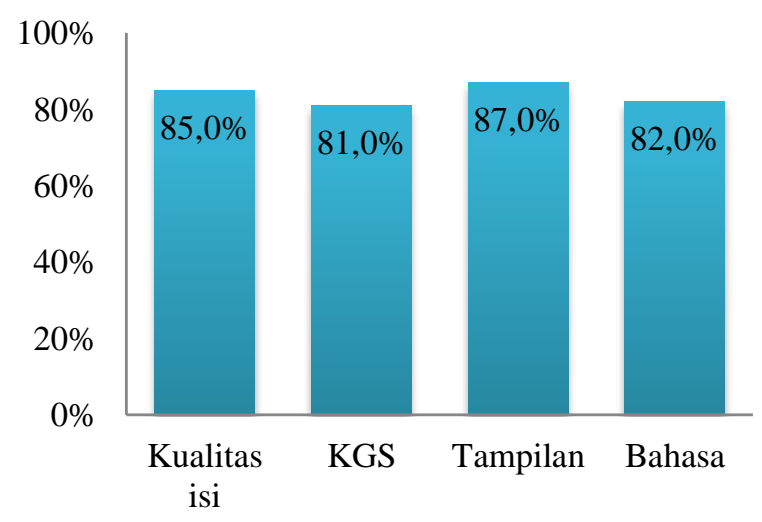

Picture 16. Student Response Result Chart.

Based on the field test and the final revision, a chemistry pocketbook product containing generic science skills on reaction rate material was valid based on the validity test, very practical based on the practical test, and received a very good response from students response test.

\section{CONCLUSION}

Based on the results of the research that has been carried out, it can be concluded that the chemistry pocketbook containing generic science skills produced is declared valid with a validity level of $76.3 \%$ based on the assessment of material experts and media experts. The pocketbook received a very good response from 
students with a percentage gain of $84.2 \%$ based on a limited trial to 10 students of class XII IPA 3 Senior High School. The pocketbook was also very practical, with a practicality level of $81.2 \%$ based on the chemistry teacher's assessment.

The research shows that the use of pocketbooks makes learning more fun and interesting for students because of the attractive design of pocketbooks and printed in color. In addition, the small size of the book can make it easier for students to carry it and use it anytime and anywhere. The presentation of reaction rate material containing generic science skills is presented briefly and clearly, making it easier for students to understand material concepts and solve science problems to improve the quality of student learning outcomes.

The researcher recommends for further research that a pocketbook product containing generic science skills in this reaction rate material be carried out in further trials in the broader group so that the level of effectiveness can be known and can be widely used in the future to support its learning.

\section{REFERENCES}

Ami, M. S., Susantini, E., \& Raharjo. (2012). Pengembangan Buku Saku Materi Sistem Ekresi Manusia di SMA/MA Kelas XI. BioEdu, 1(2), 10-13.

BSNP. (2014). Penilaian Buku Teks Pelajaran Kimia untuk Siswa SMA/MA. Jakarta: Departemen Pendidikan Nasional.

Kristianingsih, D. D. (2016). Pengembangan LKS Fisika Bermuatan Generik Sains untuk Meningkatkan Higher Order Thinking (HOTS) Siswa. Journal of Innovation Science Education, 5(1), 73-81.

Mujiyanti, A. R., Hakim, A., \& Hadisaputra, A. (2020).
Pengembangan Modul Praktikum Generik Sains Kimia Bahan Alam: Isolasi Asam Anakardat dari Kulit Biji Jambu Mete. Chemistry Education Practic, 3(2), 91-98.

Mustari, M., \& Sari, Y. (2017). Pengembangan Media Gambar Berupa Buku Saku Fisika SMP Pokok Bahasan Suhu dan Kalor. Jurnal Ilmiah Pendidikan Fisika AlBiruni, 6(1), 113-123.

Rahmawati, N. L., Sudarmin, \& Pukan, K. K. (2013). Pengembangan Buku Saku IPA Terpadu Bilingual dengan Tema Bahan Kimia dalam Kehidupan sebagai Bahan Ajar di MTS. UNNES Science Education Journal, 2(1), 157-164.

Riduwan. (2012). Skala Pengukuran Variabel-Variabel Penelitian.

Bandung: Alfabeta.

Rosidah, T., Astuti, A. P., \& Wulandari, A. V. (2017). Eksplorasi Keterampilan Generik Sains Siswa pada Mata Pelajaran Kimia di SMA Negeri 9 Semarang. Jurnal Pendidikan Sains (JPS), 5(2), 131-137.

Salim, P., \& Salim, Y. (1991). Kamus Bahasa Indonesia Kontemporer. Jakarta: Modern English Press.

Sanjaya, W. (2013). Penelitian Pendidikan: Jenis, Metode, Prosedur. Jakarta: Kencana.

Satrianingsih, C. J., Haryani, S., \& Dewi, N. (2017). Model Pembelajaran Berbasis Masalah Berbantuan Science Pocket Book untuk Meningkatkan Kemampuan Kognitif dan Sikap Terhadap Sains. Journal of Innovative Science Education, 6(2), 273-281.

Sudianah, S., Makhrus, M., \& Taufik, M. (2021). Keterampilan Generik Sains Melalui Model Pembelajaran Perubahan Konseptual pada Materi Alat-Alat Optik Peserta Didik. Jurnal Pijar MIPA, 16(1), 18-23.

Sukmadinata, N. S. (2006). Metode Penelitian Pendidikan. Bandung: PT Remaja Rosdakarya. 
Sulistyani, N. H., Jamzuri, \& Raharjo, D. (2013). Perbedaan Hasil Belajar Siswa antara Menggunakan Media Pocket Book dan Tanpa Pocket Book pada Materi Kinematika Gerak Melingkar Kelas X. Jurnal Pendidikan Fisika, 1(1), 164-172.

Tawil, M., \& Liliasari. (2014). Keterampilan-Keterampilan Sains dan Implementasinya dalam Pembelajaran IPA. Makassar: Badan Penerbit UNM.

Trianto. (2010). Pengantar Penelitian Pendidikan Bagi Pengembangan Profesi Pendidikan dan tenaga Kependdidikan. Jakarta: Kencana.

Wati, N. T., Erviyenni, \& Holiwarni, B. (2019). Pengembangan Bahan Ajar dalam Bentuk Buku Saku pada Pokok Bahasan Asam Basa. Jurnal Pendidikan Kimia Universitas Riau, 4(2), 36-46.

Winarti, Wijianto, \& Winarto. (2018). Analisis Sumber Belajar Mata Pelajaran Pendidikan Pancasila dan Kewarganegaraan di SMA Negeri 1 Kartasura. Jurnal Educitizen, 3(1), 242-258.

Wulandari, T., Prihandono, T., \& Handayani, R. D. (2016). Pengembangan Pocket Book Sahabat IPA pada Materi Indra Pendengaran dan Sistem Sonar di SMP. Jurnal Pembelajaran Fisika, 5(3), 277-284.

Zuhra, F., Hasan, M., \& Safitri, R. (2017). Model Pembelajaran Learning Cycle 7E Berbantuan Buku Saku terhadap Hasil Belajar Siswa SMA. Jurnal Pendidikan Sains Indonesia, 5(1), 134-159. 